\title{
ANALISIS REPRESENTASI MATEMATIS SISWA DALAM MENYELESAIKAN MASALAH MATEMATIKA BERDASARKAN TAHAPAN KRULIK DAN RUDNICK DITINJAU DARI ADVERSITY QUOTIENT
}

\author{
Setya Dewi ${ }^{1}$, Dinawati Trapsilasiwi ${ }^{2}$, Randi Pratama Murtikusuma ${ }^{2}$, Didik Sugeng \\ Pambudi², Ervin Oktavianingtyas $^{2}$ \\ Program Studi Pendidikan Matematika, FKIP, Universitas Jember \\ J1. Kalimantan 37 Kampus Tegalboto, Jember 68121 \\ E-mail: setyadewi567@gmail.com
}

\begin{abstract}
This research purpose to describe the mathematical representation abilities of students based on the Krulik and Rudnick stages in terms of students' AQ. This research type is qualitative descriptive research. The research location is in SMAN Darussholah Singojuruh with the subjects of class XI MIPA 3 and XI MIPA 7 as many as 30 students. The data collecting methods used test and interview methods, with research instruments, such as Adversity Response Profile questionnaire, mathematics test, interview guidelines, and validation sheets. Based on the test result data analysis and interview data analysis, the following results were obtained, such as 1) Climber students could solve linear program questions based on Krulik and Rudnick stages coherently, and be able to used forms of verbal representations, visual representations, and mathematical expressions properly and correctly; 2) Camper students could solve linear program questions based on Krulik and Rudnick stages coherently but had not been able to use forms of verbal representations, visual representations, and mathematical expressions properly and correctly; 3) Quitter students had not been able to solve linear program questions based on Krulik and Rudnick stages correctly and had not been able to use their verbal representation, visual representation, and mathematical expression skills properly.
\end{abstract}

Keywords: Mathematical Representation, Krulik and Rudnick, Adversity Quotient

\section{PENDAHULUAN}

Kemampuan berpikir dalam pembelajaran matematika merupakan tindakan yang dilakukan siswa untuk menyelesaikan permasalahan pada saat proses pembelajaran berlangsung. Terdapat lima standar proses kemampuan berpikir matematika, yaitu pemecahan masalah, berargumentasi, komunikasi, koneksi, dan representasi [1]. Representasi merupakan interpretasi pemahaman atau pemikiran siswa berupa ide-ide yang terbentuk di dalam pikirannya terhadap suatu permasalahan tertentu dan dikomunikasikan melalui istilah, tulisan, gambar, simbol, atau benda konkrit yang ]memudahkan siswa dalam menyelesaikan masalah [2][3]. Representasi berperan untuk mengembangkan dan mengoptimalkan kemampuan matematika yang dimiliki siswa, dengan menciptakan koneksi suara antara dunia nyata dan dunia abstrak diharapkan siswa dapat membangun fondasi yang kuat untuk pemikiran matematika [3-5].

Kemampuan representasi sangat penting dan erat kaitannya dengan langkah penyelesaian masalah. Dengan menggunakan langkah penyelesaian masalah, siswa diharapkan lebih runtut dan terstruktur ketika menyelesaikan masalah matematika.

\footnotetext{
${ }^{1}$ Mahasiswa S1 Prodi Pendidikan Matematika FKIP Universitas Jember

${ }^{2}$ Dosen Prodi Pendidikan Matematika FKIP Universitas Jember
} 
Terdapat beberapa model langkah penyelesaian masalah, yaitu: Polya, Alan $\mathrm{H}$. Schoenfeld, James W.Willson \& Colleagues, John Mason \& Colleagues, dan Krulik \& Rudnick [6]. Secara umum, langkah penyelesaian masalah terdiri dari tahapan membaca, menganalisis, mengeksplorasi, merencanakan/mengimplementasikan, dan memverifikasi [7]. Pada penelitian ini menggunakan langkah penyelesaian masalah berdasarkan tahapan Krulik dan Rudnick, yaitu: membaca, mengeksplorasi, memilih strategi, menyelesaikan, melihat kembali dan mengembangkan [8].

Permasalahan matematika biasanya disajikan berupa soal cerita, penggambaran kejadian/fenomena alam, teka-teki, atau ilustrasi gambar. Salah satu materi atau pokok bahasan dalam matematika yang sering digunakan untuk soal cerita adalah materi program linier. Dipilihnya materi program linier pada penelitian ini, dikarenakan materi tersebut dapat memberikan beberapa bentuk representasi matematis ketika siswa mencari solusi dari penyelesaian masalah pada soal program linier. Bentuk representasi yang dapat dimunculkan dalam penyelesaian soal program linier yaitu representasi visual, representasi verbal, dan persamaan/ekspresi matematis.

Setiap siswa memiliki tingkat kemampuan representasi yang berbeda, sesuai dengan konsep yang ia pahami. Untuk mengetahui seberapa baik kemampuan representasi matematis siswa, diperlukan sebuah kerangka berpikir untuk mengklasifikasikan siswa ke dalam tingkatan tertentu. Pengklasifikasian ini diperlukan untuk mengetahui perbedaan hasil representasi yang dimiliki setiap siswa. Klasifikasi yang digunakan dalam penelitian ini berdasarkan Adversity Quotient (AQ) siswa. Adversity Quotient merupakan bentuk kecerdasan manusia yang bertujuan untuk mengatasi sebuah kesulitan [9]. Dipilihnya klasifikasi ini, dikarenakan strategi siswa ketika menyelesaikan masalah matematika sangat dipengaruhi oleh daya juang $/ A Q$. Siswa dengan tingkatan $A Q$ berbeda tentunya memiliki proses berpikir yang berbeda juga.

Menurut beberapa penelitian, kemampuan representasi matematis setiap siswa berbeda-beda. Baik ketika ditinjau dari motivasi atau minat belajar, maupun kecerdasan afektif dan jenis kelamin. Dari penelitian tersebut didapatkan hasil bahwa kemampuan representasi matematis yang dimiliki siswa ketika menyelesaikan masalah matematika masih rendah, serta didapatkan jawaban yang bervariasi [10-13]. Keberagaman jawaban tersebut dipengaruhi oleh kemampuan awal matematika dan $A Q$ siswa. Oleh karena itu, peneliti ingin membahas lebih lanjut terkait kemampuan representasi matematis siswa berdasarkan tahapan Krulik dan Rudnick yang ditinjau dari $A Q$ siswa.

\section{METODE PENELITIAN}

Penelitian ini menggunakan jenis penelitian deskriptif dengan pendekatan kualitatif. Penelitian dilakukan di SMAN Darussholah Singojuruh dengan subjek penelitian kelas XI MIPA 3 dan XI MIPA 7. Subjek penelitian dipilih menggunakan metode purposive sampling, yaitu berdasarkan pertimbangan dari guru matematika di sekolah tersebut. Pertimbangan yang dimaksud ialah pemilihan kelas yaitu regular dan unggulan yang diharapkan dapat memberikan hasil yang berbeda tiap siswa. Instrumen penelitian yang digunakan yaitu angket Adversity Response Profile (ARP), soal tes matematika materi program linier, pedoman wawancara, dan lembar validasi. Pemberian angket bertujuan untuk mengkategorikan siswa ke dalam tiga tingkatan, yaitu AQ tinggi (climber), AQ sedang (camper), dan AQ rendah (quitter). Metode pengumpulan data menggunakan metode tes tulis dan wawancara. Tes tulis berupa soal uraian materi program linier. Soal tersebut bertujuan untuk mengetahui kemampuan representasi matematis yang dimiliki siswa berdasarkan tahapan Krulik dan Rudnick. 
Responden wawancara yaitu dua siswa dari masing-masing tingkatan AQ yang memiliki selisih skor ARP yang signifikan (skor antara AQ Climber, Camper, dan Quiter). Indikator yang digunakan dalam penelitian ini merupakan hasil kombinasi dari indikator representasi matematis dengan indikator penyelesaian masalah berdasarkan tahapan Krulik dan Rudnick. Analisis representasi matematis siswa berdasarkan tahapan Krulik dan Rudnick dapat dilihat pada Tabel 1.

Tabel 1. Indikator Representasi Matematis Berdasarkan Tahapan Krulik dan Rudnick

\begin{tabular}{cl}
\hline $\begin{array}{c}\text { Tahapan Krulik } \\
\text { dan Rudnick }\end{array}$ & \multicolumn{1}{c}{ Bentuk Representasi Matematis } \\
\hline $\begin{array}{c}\text { Membaca } \\
(\text { Read })\end{array}$ & $\begin{array}{l}\text { Menuliskan kembali informasi yang diberikan (Representasi Verbal) } \\
\text { Menuliskan apa yang ditanyakan pada soal (Representasi Verbal) }\end{array}$ \\
\hline $\begin{array}{c}\text { Mengeksplorasi } \\
(\text { Explore })\end{array}$ & $\begin{array}{l}\text { Membuat tabel dari informasi yang diberikan (Representasi Visual) } \\
\text { Membuat model matematika dari permasalahan pada soal (Ekspresi } \\
\text { Matematis) }\end{array}$ \\
\hline Memilih Strategi & Menulis strategi yang akan digunakan untuk menyelesaikan soal \\
(Select Strategy) & (Representasi Verbal) \\
\hline & Menyajikan penyelesaian masalah menggunakan diagram, tabel, atau \\
& grafik (Representasi Visual) \\
Menggunakan keterampilan geometri untuk menggambarkan daerah \\
penyelesaian (Representasi Visual) \\
(Solve) & $\begin{array}{l}\text { Menggunakan keterampilan komputasi untuk mencari jawaban akhir } \\
\text { (Ekspresi Matematis) }\end{array}$ \\
& Menuliskan kesimpulan dari permasalahan yang diberikan \\
(Representasi Verbal)
\end{tabular}

\section{HASIL DAN PEMBAHASAN}

Penelitian dilakukan di SMAN Darussholah Singojuruh dengan subjek penelitian siswa kelas XI MIPA 3 dan XI MIPA 7 sebanyak 30 siswa. Berdasarkan hasil pengisian angket ARP, didapatkan masing-masing kategori AQ yaitu Climber, Camper, dan Quitter yang disajikan pada gambar diagram berikut.

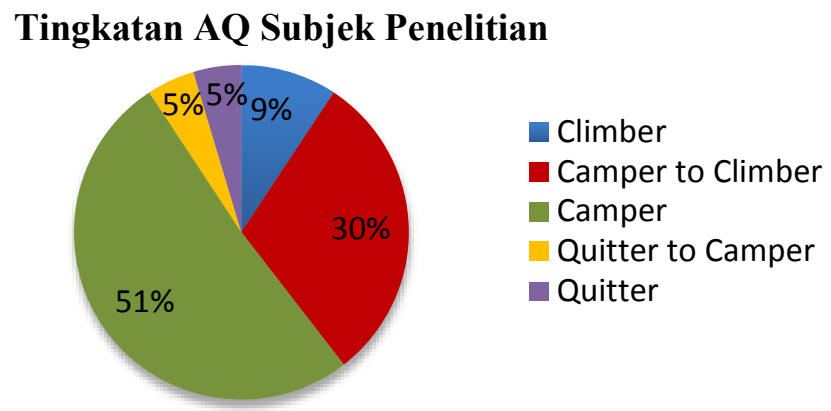

Gambar 1. Gambar Diagram Tingkatan AQ Subjek Penelitian 
Pemilihan responden wawancara berdasarkan subjek penelitian yang memiliki perbedaan skor ARP yang signifikan, yaitu skor antara AQ Climber, Camper, dan Quitter. Daftar responden wawancara dalam penelitian ini disajikan pada Tabel 2.

Tabel 2. Subjek sebagai Responden Wawancara

\begin{tabular}{cccc}
\hline No & Kode & Tingkatan AQ & Skor ARP \\
\hline 1 & CL1 & Climber & 168 \\
\hline 2 & CL2 & Climber & 167 \\
\hline 3 & CP3 & Camper & 133 \\
\hline 4 & CP4 & Camper & 126 \\
\hline 5 & Q5 & Quitter & 50 \\
\hline 6 & Q6 & Quitter & 45 \\
\hline
\end{tabular}

Berdasarkan hasil penelitian untuk subjek dengan tingkatan AQ Climber, Camper, dan Quitter, hasil analisis kemampuan representasi matematis siswa berdasarkan tahapan Krulik dan Rudnick pada setiap tahap penyelesaian dapat dilihat pada Tabel 3.

Tabel 3. Analisis Data Hasil Tes

\begin{tabular}{|c|c|c|c|c|}
\hline $\begin{array}{l}\text { Tahapan Krulik } \\
\text { dan Rudnick }\end{array}$ & Bentuk Representasi Matematis & $\begin{array}{l}\text { Climber } \\
\text { (CL) }\end{array}$ & $\begin{array}{l}\text { Camper } \\
\text { (CP) }\end{array}$ & $\begin{array}{l}\text { Quitter } \\
\text { (Q) }\end{array}$ \\
\hline \multirow{2}{*}{$\begin{array}{l}\text { Membaca } \\
(\text { Read })\end{array}$} & $\begin{array}{l}\text { Menuliskan kembali informasi yang } \\
\text { diberikan (Representasi Verbal) }\end{array}$ & $\mathrm{T}$ & $\mathrm{T}$ & BT \\
\hline & $\begin{array}{l}\text { Menuliskan apa yang ditanyakan } \\
\text { pada soal (Representasi Verbal) }\end{array}$ & $\mathrm{T}$ & $\mathrm{T}$ & BT \\
\hline \multirow[b]{2}{*}{$\begin{array}{l}\text { Mengeksplorasi } \\
\quad \text { (Explore) }\end{array}$} & $\begin{array}{l}\text { Membuat tabel dari informasi yang } \\
\text { diberikan (Representasi Visual) }\end{array}$ & $\mathrm{T}$ & $\mathrm{T}$ & BT \\
\hline & $\begin{array}{l}\text { Membuat model matematika dari } \\
\text { permasalahan yang diberikan } \\
\text { (Ekspresi Matematis) }\end{array}$ & $\mathrm{T}$ & BT & BT \\
\hline $\begin{array}{l}\text { Memilih Strategi } \\
\text { (Select Strategy) }\end{array}$ & $\begin{array}{l}\text { Menulis strategi yang akan } \\
\text { digunakan untuk menyelesaikan soal } \\
\text { (Representasi Verbal) }\end{array}$ & $\mathrm{T}$ & $\mathrm{T}$ & BT \\
\hline \multirow{4}{*}{$\begin{array}{l}\text { Menyelesaikan } \\
\quad \text { (Solve) }\end{array}$} & $\begin{array}{l}\text { Menyajikan penyelesaian masalah } \\
\text { menggunakan diagram, tabel, atau } \\
\text { grafik (Representasi Visual) }\end{array}$ & $\mathrm{T}$ & $\mathrm{T}$ & BT \\
\hline & $\begin{array}{l}\text { Menggunakan keterampilan geometri } \\
\text { untuk menggambarkan daerah } \\
\text { penyelesaian (Representasi Visual) }\end{array}$ & $\mathrm{T}$ & BT & BT \\
\hline & $\begin{array}{l}\text { Menggunakan keterampilan } \\
\text { komputasi untuk mencari jawaban } \\
\text { akhir (Ekspresi Matematis) }\end{array}$ & $\mathrm{T}$ & $\mathrm{BT}$ & BT \\
\hline & $\begin{array}{l}\text { Menuliskan kesimpulan dari } \\
\text { permasalahan yang diberikan } \\
\text { (Representasi Verbal) } \\
\end{array}$ & $\mathrm{T}$ & BT & BT \\
\hline \multirow{2}{*}{$\begin{array}{c}\text { Melihat Kembali } \\
\& \\
\text { Mengembangkan } \\
\text { (Look Back and } \\
\text { Extend) }\end{array}$} & $\begin{array}{l}\text { Menuliskan tingkat keyakinan atau } \\
\text { kebenaran jawaban pada lembar } \\
\text { jawaban (Representasi Verbal) }\end{array}$ & $\mathrm{T}$ & $\mathrm{T}$ & BT \\
\hline & $\begin{array}{l}\text { Memverifikasi jawaban dengan } \\
\text { menulis ulang jawaban yang benar } \\
\text { jika terdapat kesalahan (Representasi } \\
\text { Verbal) }\end{array}$ & $\mathrm{T}$ & $\mathrm{BT}$ & BT \\
\hline
\end{tabular}

Keterangan : 
T : Indikator Terpenuhi

BT : Indikator Belum Terpenuhi

Berdasarkan analisis data hasil soal tes program linier dan kegiatan wawancara, siswa dengan tingkatan AQ Climber mampu menggunakan kemampuan representasi matematisnya untuk menyelesaikan seluruh soal dengan baik dan benar, serta memiliki jawaban yang kompleks dan terstruktur. Siswa Climber mampu memenuhi seluruh indikator representasi matematis berdasarkan tahapan Krulik dan Rudnick (Tabel 1). Hal tersebut sesuai dengan hasil penelitian relevan yang menyatakan bahwa siswa Climber dapat menggunakan seluruh bentuk representasi (verbal, visual, dan ekspresi matematis) ketika menyelesaikan suatu masalah dan mampu melakukan seluruh tahapan pemecahan masalah dengan baik, yaitu memahami masalah, merencanakan penyelesaian, melaksanakan perencanaan, dan memeriksa kembali [14][15]. Berikut hasil analisis representasi matematis pada lembar jawaban siswa Climber.

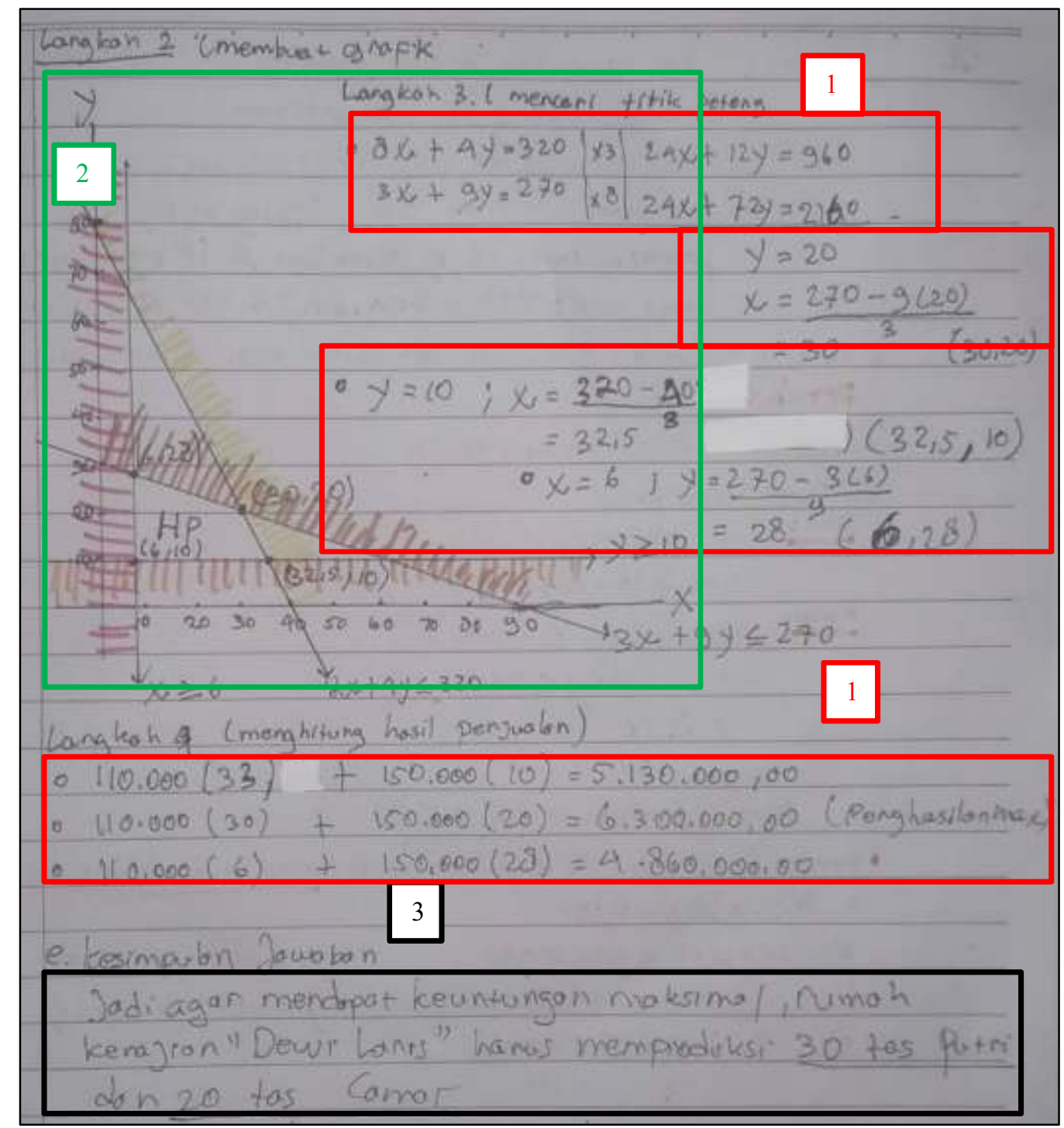

Gambar 2. Lembar Jawaban Siswa Climber

Keterangan:

1. Ekspresi Matematis

2. Representasi Visual 


\section{Representasi Verbal}

Berdasarkan analisis data hasil soal tes program linier dan kegiatan wawancara, siswa dengan tingkatan AQ Camper mampu menggunakan kemampuan representasi matematisnya untuk menyelesaikan seluruh soal yang diberikan, namun jawaban akhir masih belum benar. Siswa tidak dapat membuat model matematika dengan benar, sehingga mengakibatkan kesalahan dalam proses perhitungan jawaban akhir. Hal tersebut sesuai dengan penelitian relevan yang mengatakan bahwa siswa camper tidak dapat memodelkan informasi dan merasa kesulitan dengan soal yang diberikan [16]. Pada saat wawancara, siswa camper merasa puas dengan hasil pekerjaanya, sehingga ia tidak melakukan koreksi ulang. Hal tersebut juga sesuai dengan penelitian relevan dan pendapat Stoltz yang menyatakan bahwa seseorang dengan tipe camper merupakan tipe yang cepat puas dengan hasil yang sudah dicapai [9][17]. Berikut hasil analisis representasi matematis pada lembar jawaban siswa Camper.

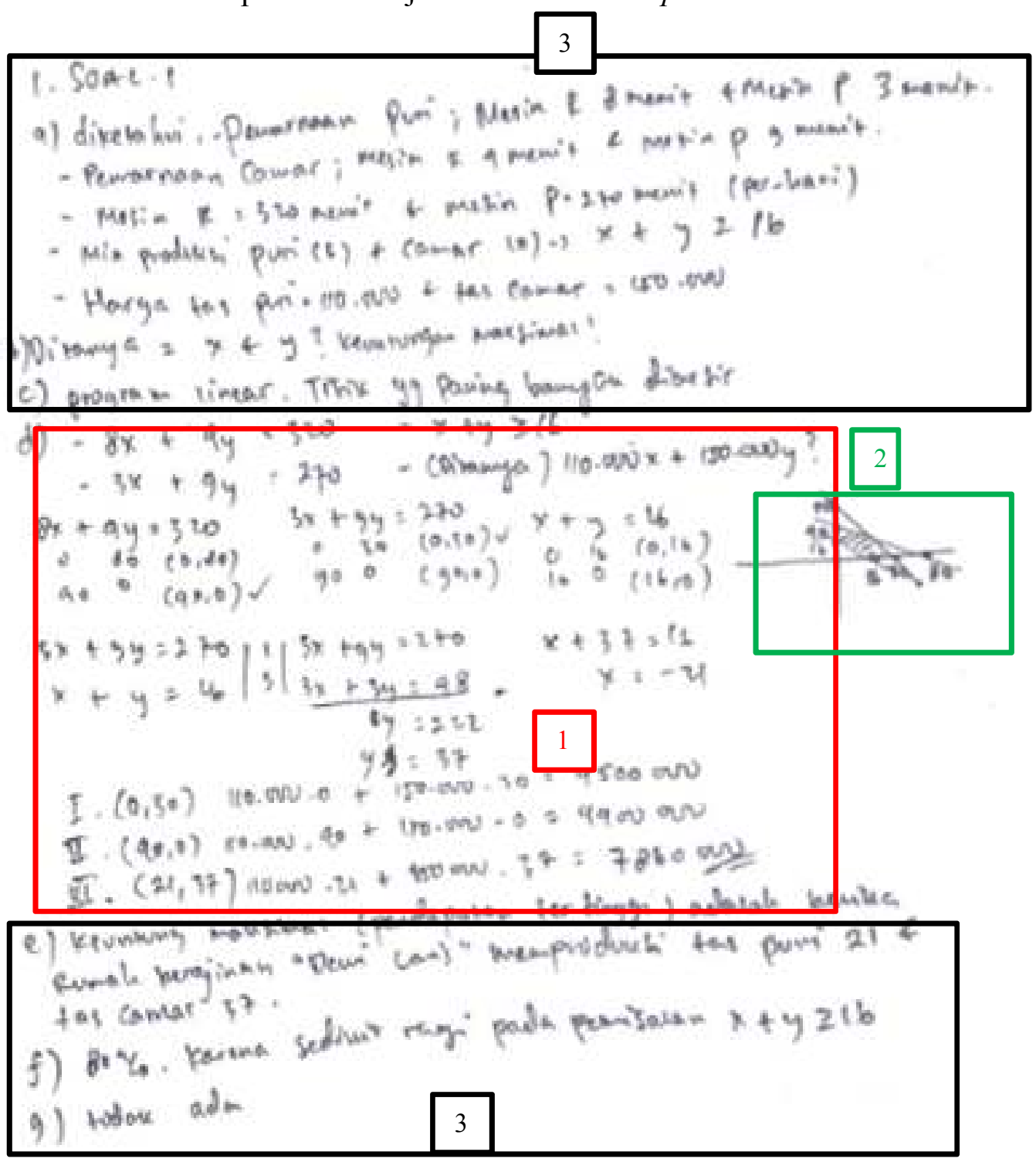

Gambar 3. Lembar Jawaban Siswa Camper

Keterangan:

1. Ekspresi Matematis

2. Representasi Visual 


\section{Representasi Verbal}

Berdasarkan analisis data hasil soal tes program linier dan kegiatan wawancara, siswa dengan tingkatan AQ Quitter belum mampu menggunakan kemampuan representasi matematisnya untuk menyelesaikan seluruh soal dengan baik dan benar. Hal tersebut terlihat pada saat wawancara bahwa siswa Quitter tidak bisa memahmi maksud dari soal, sehingga ia hanya menulis seadanya dan tidak bisa menjelaskan ulang pada saat wawancara. Bentuk representasi yang terlihat hanya representasi verbal saja, namun masih belum tepat. Siswa Quitter tidak berusaha untuk menyelesaikan soal, sehingga ia tidak menampilkan bentuk representasi dengan benar. Hal tersebut sesuai dengan penelitian relevan yang menyatakan bahwa siswa Quitter tidak bisa menampilkan berbagai macam bentuk representasi dengan tepat dan benar [14]. Berikut hasil analisis representasi matematis pada lembar jawaban siswa Quitter.

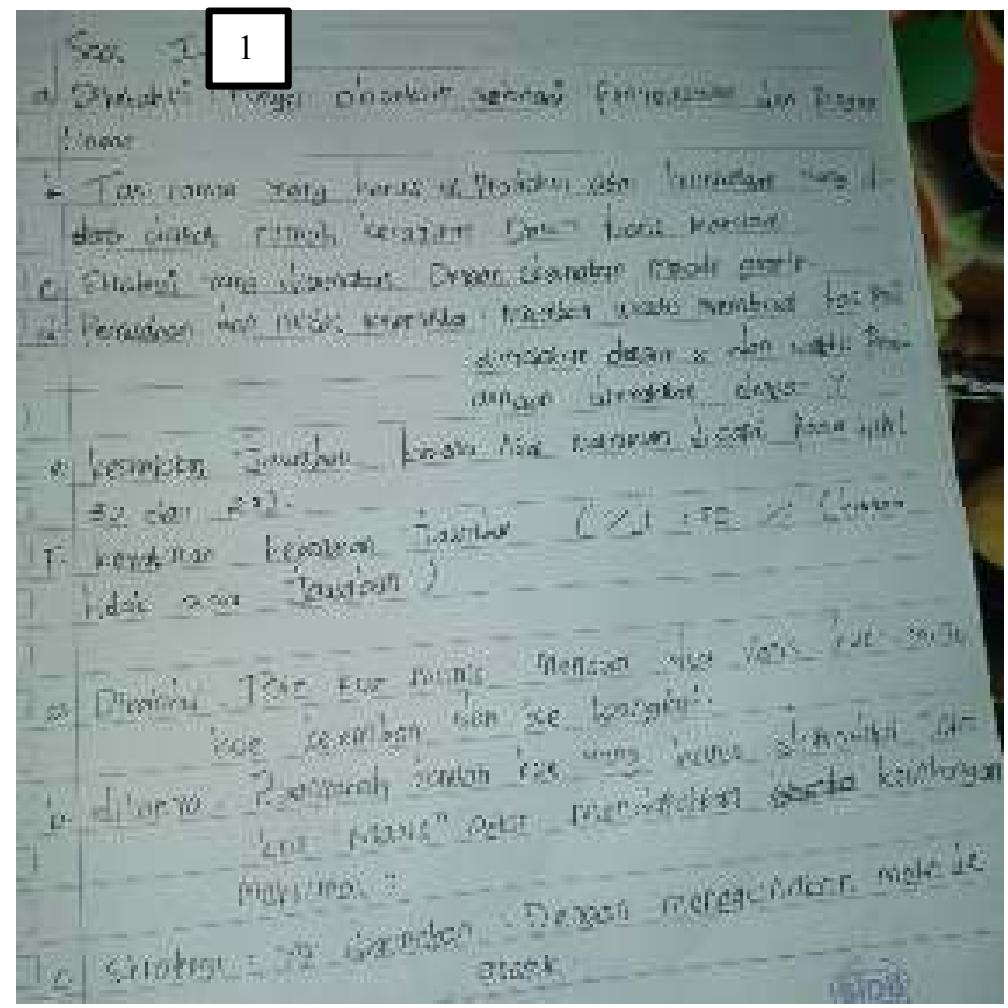

Gambar 4. Lembar Jawaban Siswa Quitter

Keterangan:

1. Representasi Verbal

Dari ketiga tingkatan AQ Climber, Camper, dan Quitter, siswa bisa menggunakan bentuk representasi visual, representasi verbal, dan ekspresi matematis ketika menyelesaikan soal tersebut, meskipun jawaban yang diperoleh masih belum tepat. Siswa Climber dapat menyelesaikan soal dengan runtut dan benar, serta dapat menampilkan ketiga bentuk representasi. Siswa Camper dapat mengerjakan secara runtut dan dapat menampilkan ketiga bentuk representasi, namun jawaban akhir yang diperoleh masih belum benar. Siswa Quitter tidak bisa menyelesaikan soal sampai akhir dan hanya menampilkan bentuk representasi verbal, tetapi belum benar. Siswa Climber memiliki semangat yang tinggi untuk bisa menyelesaikan permasalahan yang dihadapinya. Hal ini terlihat ketika wawancara, ia berusaha untuk mengecek kembali pekerjaannya agar mendapatkan hasil sesuai harapan. Semangat siswa Camper tidak sebesar Climber. Hal ini dapat dilihat ketika wawancara, ia merasa lega ketika 
mendapatkan jawaban tanpa mau mengeceknya kembali. Untuk siswa Quitter, ia tidak memiliki usaha lebih untuk bisa menyelesaikan permasalahan yang dihadapinya.

\section{KESIMPULAN}

Berdasarkan hasil dan pembahasan, maka dapat disimpulkan yaitu: 1) siswa dengan tingkatan AQ Climber mampu menyelesaikan masalah program linier berdasarkan tahapan Krulik dan Rudnick dengan baik dan benar, serta bentuk representasi yang digunakan ialah representasi visual, representasi verbal, dan ekspresi matematis; 2) siswa dengan tingkatan AQ Camper belum mampu menyelesaikan masalah program linier berdasarkan tahapan Krulik dan Rudnick dengan baik dan benar. Pada tahapan mengeksplorasi (explore), siswa salah membuat model matematika, sehingga untuk perhitungan selanjutnya juga salah. Bentuk representasi yang digunakan ialah representasi visual dan representasi verbal; 3) siswa dengan tingkatan AQ Quitter belum mampu menyelesaikan masalah program linier berdasarkan tahapan Krulik dan Rudnick. Pada tahapan membaca (read), siswa belum mampu memahami soal beserta informasinya dengan baik, sehingga siswa tidak dapat melanjutkan ketahapan berikutnya. Selain itu, dari ketiga bentuk representasi tidak ada satu pun yang dapat dijawab dengan tepat.

\section{DAFTAR PUSTAKA}

[1] NCTM (National Council of Teachers of Mathematics). (2000). Principles and Standars for School Mathematics. Reston, VA: Author.

[2] Huda, U., Musdi, E. \& Nari, N. (2019). Analisis Kemampuan Representasi Matematis Siswa dalam Menyelesaikan Soal Pemecahan Masalah Matematika. TA'DIB, 22(1), 19-26.

[3] Sabirin, M. (2014). Representasi Dalam Pembelajaran Matematika. JPM IAIN Antasari, 1, 33-44.

[4] Zulfakri, Ikhsan, M. \& Yusrizal. (2019). Improving the Ability of Representation and Problem Solving Through Concrete Representational Abstract ( CRA ) Approach in Mathematical Learning. International Journal for Educational and Vocational Studies, 1(3), 244-248. https://doi.org/https://doi.org/10.29103/ijevs.v1i3.1585

[5] Chen, M., Lee, C. \& Hsu, W.-C. (2015). Influence of Mathematical Representation and Mathematics Self-Efficacy on the Learning Effectiveness of Fifth Graders in Pattern Reasoning. International Journal of Learning, Teaching, and Educational Research, 13(1), 1-16.

[6] Rott, B. (2011). Models of the Problem Solving Process - a Discussion Referring to the Processes of Fifth Graders. In T. Bergqvist (Ed.), ProMath Conference (hal. 95-107). Umea University.

[7] Galbraith, P., Goos, M. \& Renshaw, P. (2000). A Money Problem : A Source of Insight into Problem Solving Action. 1-21.

https://www.researchgate.net/publication/43487463 A

[8] Krulik, S. \& Rudnick, J. A. (1988). Problem Solving: A Handbook for Elementary School Teachers. Boston, DC: Author.

[9] Stoltz, P. G. (1997). Adversity Quotient: Turning Obstacles into Opportunities. Kanada: John Wiley \& Sons. 
[10] Widodo, A. N. A. \& Aristiyo, D. N. (2019). Kemampuan Representasi Matematis Mahasiswa Dalam Menyelesaikan Masalah Statistika Berdasarkan Langkah Krulik dan Rudnick. JES-MAT, 5(2), 99-112.

[11] Murtianto, Y. H., Suhendar, A. \& Sutrisno. (2019). Analisis Kemampuan Representasi Verbal Siswa Dalam Pemecahan Masalah Matematika Berdasarkan Tahapan Krulik dan Rudnick Ditinjau dari Motivasi Belajar Siswa. Jurnal Ilmiah Pendidikan Matematika, 4, 77-84.

[12] AR, R. A. \& Mahmud, N. (2019). Analysis of University Students 'Mathematical Representation in Solving Geometry Problems. International Conference on Advanced Multidisciplinary Research (ICAMR), 227, 34-37.

[13] Komala, E. \& Suryadi, D. (2018). Analysis of internal and external mathematical representation ability to senior high school students in Indonesia. International Conference on Mathematical Sciences and Statistics, 1-10. https://doi.org/10.1088/1742-6596/1132/1/012047

[14] Mahendra, N. R., Isnarto \& Mulyono. (2020). Mathematics Representation Ability Viewed from Adversity Quotient in SAVI Learning. Unnes Journal of Mathematics Education Research (UJMER), 9(2), 199-207.

[15] Septiani, E. S. \& Nurhayati, E. (2019). Analisis Kemampuan Pemecahan Masalah Matematis Ditinjau Dari Adversity Quotient (AQ) Peserta Didik Melalui Model Problem Based Learning (PBL). Prosiding Seminar Nasional \& Call For Papers, $168-175$.

[16] Suhandoyo, G. \& Wijayanti, P. (2016). Profil Kemampuan Berpikir Kreatif Siswa Dalam Menyelesaikan Soal Higher Order Thinking Ditinjau dari Adversity Quotient (AQ). Jurnal Ilmiah Pendidikan Matematika, 3(5), 156-165.

[17] Rahmawati, N. D., Mardiyana \& Usodo, B. (2015). Profil Siswa SMP Dalam Pemecahan Masalah Yang Berkaitan Dengan Literasi Matematis Ditinjau Dari Adversity Quotient (AQ). Jurnal Elektronik Pembelajaran Matematika, 3(5), 508517. 